\title{
Win-Win Managing
}

\author{
Kuang-Ming Wu \\ Philosophy Department, University of Wisconsin-Oshkosh, Oshkosh, WI, USA \\ Email: Kmwu2002@yahoo.com
}

How to cite this paper: $\mathrm{Wu}, \mathrm{K} .-\mathrm{M}$. (2017). Win-Win Managing. Sociology Mind, 7 $81-101$.

https://doi.org/10.4236/sm.2017.73007

Received: April 27, 2017

Accepted: July 1, 2017

Published: July 4, 2017

Copyright $\odot 2017$ by author and Scientific Research Publishing Inc. This work is licensed under the Creative Commons Attribution International License (CC BY 4.0).

http://creativecommons.org/licenses/by/4.0/

\begin{abstract}
In win-win management, you win because I win. In zero-sum game, you lose because I win. In the win-win, joys abound. In the zero-sum, losers abound into social instability. Art of living packs all arts to culminate in the beautiful art of win-win management. Many fabulous consequences are packed hereselfishness self-rotting, mother and child inter-winning, kids, forgiving, grateful always, loving enemies, commerce, etc. This essay has introduction, art of living, and conclusion, to invite life-enjoyment all around.
\end{abstract}

\section{Keywords}

Win-Win, Zero-Sum, Forgiving, Commerce

\section{Introduction}

“Tell your dear 'selfish' daughter, my dear friend. 'Sharing' benefits me, not hoarding. Surprised? Let me explain in two points. One, Japan says, 'Feeling for others is not for others' but for me. As I feel for you, I care for you. By and by, you will come to care for me, in your hope that I'd keep caring for you. And I do continue to care for you feelingly. What goes around comes around. In caring feelingly, what goes around comes around back to me. Sharing benefits me.

Two, she may say, 'But we all have needs more numerous than there are things to satisfy our needs.' Well, if so, we can share our needs. I need to make money. You need a loaf of bread. OK, then, I give you bread you need, and you give me money for it. Such is 'selling and buying.' International commerce is booming more than nationalism.

In all, then, sharing benefits me, but no hoarding does. Your dear daughter is smart. She will get the point."

Now, this is an actual story. This story naturally tells aloud how we must win together to win-win. We simply die away, one and all, as soon as we stop winning together, one and all. And this actual story, by telling us so, also loudly shows us how, by sharing, we all win-win winning together, one and all. This 
story concretely portrays win-win management to thrive together one with the other.

Our central theme is win-win management. "Management" manages affairs. "Affairs" is human affairs. Management by manipulation of issues must be replaced by dealings with human persons. The best dealing with persons is to manage affairs in such a way as to let win-win to win together. This win-win management has no room for failure, for failure here is to have someone fail to win, and when everyone wins, there is no room for failing to win.

China's great victory-strategist Sun Tzu 孫子 proposed winning over the entire enemy by winning all their hearts and feelings. But he proposed this complete victory over the enemy without killing them, by overcoming them with threats and with deceptions. This famous book is usually mistranslated as "The Art of War," while actually the book is about how to use soldiers to win victory with no war. The book is rightly titled the "art of soldiery 兵法" (Wu, 2006). He did not go so far as "I win because you win, while you win because I win." In other words, he did not propose win-win management, and besides, this winwin management is performed without deception but with sincere tender loving care, heartfelt for "your" needs. The present paper details this delightful win-win management that is unique and quite feasible, and with no room for failure.

\section{What Win-Win Management Is}

To begin with, in "making love" as sexual intercourse, I am happy because I make you happy. In "making love" in all other social intercourses, I am also happy because I make you happy. Here, "because" is important. This "because" is structured with care. Caring for you induces me to share my joy with you. Care means the bed of trouble, sys the Oxford English Dictionary under "care."

Caring feels for others in pain. When you are in sheer lack of joy, care comes in co-pathos in com-passion, which is co-suffering, so as to share my joy with you who are not in joy. Thus, such caring for joys spreads. Caring is at the center of sharing that makes happiness to go around everywhere. What goes around to you in my caring joy comes around to me in your caring joy. All this is how you and I share my joys to another "you," as this new you share your joys to still another "you," on and on.

The heartfelt caring is what the mother does. The mother so tenderly cares as to actually give birth to her new life to nurture its growth. In motherly joy of caring, the baby wins birth and growth because the mother wins her irreplaceable joy. Mother and baby are win-win inter-joys par excellence. It is thus that to win-win is to motherly share what I cherish and love with you who may lack whatever treasure I have, even existence.

Such caring is what the mother does to her baby, meticulously and routinely, 24 hours a day, seven days a week. Her baby in turn extends his dearest mother's own self into tomorrows. Her extension is his extension that is enabled by his precious mother. Each wins because the dearest other wins. This is how the mother's extension delightfully comes about with her baby together. Mother and 
child live on in the midst of their heartfelt win-win interaction, happily ever after.

\section{Flowing, Not Hoarding}

And so, to generalize, our sharing this motherly way is to allow things precious to flow all over continually. To win-win is then to flow all around. In flowing, all things turn alive. Hoarding rots things that die away. Hoarding kills one another. Flowing is win-win to joy-joy. What we human beings cherish is human-water that must flow uninterrupted to enrich themselves and, thereby, enrich all of us who are their beneficiaries. Otherwise, when the free flow is interrupted, things as water get rotten. Concrete examples abound.

Besides motherly tender loving care, what we usually cherish are power, money, talents, and the like (She et al., 1971). A sad example of corruption of motherly love when stopped flowing to all children is given in the famous story. Fortunately, it has a happy ending, due to resumption of mother-son inter-flow. Power corrupts when hoarded and concentrated in one person, not flowing out to other people. Dictatorial tyranny results to devastate the world. Money empowers power, and money rots away in plutocracy the money-rule to ruin people at large, with money-bought demagogueries to sway people into selfish benefits of the wealthy alone. Talents must be handed down to the late-comers who are our beloved posterity. When hoarded to one person alone, talents vanish with the gifted person who sooner than later dies away without a trace, as morning dew after sunrise.

Before we go on ahead, let us unpack the important point mentioned above. By "for me to win, for you to win" benefits, we share benefits. Sharing here is to induce things to flow all over without obstruction and without a stop. Flowing of things turns things alive. Stopping the flow rots things dead. "All is water," declared the first poet-philosopher Thales. All things are water flowing to come out jumping alive. Stopping things flowing stops things, which are now settled in sediments to rot and vanish. Flowing water of things collects no "moss" of corruption. As before, three examples come to mind, namely, power, money, and talents.

First, this is how power fares. "Power corrupts" as it is hoarded to concentrate in one person. Corruption here means dictatorship to brutalize people at large to devastate the whole world. World history is sadly and senselessly made of these world disasters in dictatorial devastations. We may be familiar with this fact. What we seldom notice is that such horrendous corruption of power originates in stopping the ubiquitous flow of power throughout people. Total flow of power among all people makes for people-power that is "democracy," as opposed to stopping power-flow into one dictatorial tyrant. Stopping power-flow corrupts power into tyranny to ruin the world.

Secondly, such is also the case with money. Money empowers power. Money not-flowing corrupts itself to corrupt power. This is because money is supposed to flow all over without hoarding, as all economists advise us. Money hoarded 
among the wealthy stunts the flow of money all over. Stunted flow stops the flow. Money not-flowing corrupts the power into plutocracy, tyranny of the wealthy. "Power corrupts" because money stops flowing and concentrates into one person or one party. Plutocracy destroys democracy. Money-rule kills people-rule. Money not flowing devastates the world in plutocracy.

Thirdly, the identical situation holds valid on talents. Talents are perishable goods. Talents must flow both from one person to another and from now to later. Stopping talent-flow in time among people stops talents, and talents vanish away. Teaching pushes the flow of talents from teacher to students, to flow from today to tomorrow. And so, education vitalizes the society through talents through time. This is because talents are the vitality of the society. The society is suffocated to death without talents, for it is talents that better the society. Bettering the society sustain it and continue to vitalize it. Without continuation of society kills the society.

It is thus that win-win management is absolutely indispensable to our surviving together. We either inter-thrive to co-survive, or else die isolated alone without sharing. We have no third alternative. "Now, how do we manage to win-win?" I offer positive stance and forgiving one another. Let us first explore positive approach in order to share benefits, and then forgiving one another in friendship. Both ways of living are unexpectedly fecund. Both powerfully prepare us to manage to win-win together in joy.

\section{Positive Stance}

To begin, in our daily living, we must continually stare at our common sense, saying that all things have two sides, positive side and negative side. And then, we must steadfastly stick to the positive side of things. This positive way of living is hard to perceive to pick up, and it is also hard to persevere to live on. In living this positive stance, we can naturally share the benefits we persistently perceive, and manage to win-win together happily ever after. "Positive" here describes how things turn on us as they turn us on. It is exciting to explain how all this happens.

Six points are here. To begin with, incredible as it may sound, all things and situations, however bad, always have two sides, positive and negative at least so we must decide to be convinced. And then, secondly, this fact-both factual and actualized-implicates our obligation to struggle to find the positive side of our days, and then stick to it. We must stubbornly struggle to actually live this positive perspective, no matter what.

All this is what we owe to our very living, especially because we-I do not know why-tend to see the negative side of things. We tend to think that there has to be something wrong in each moment. We are even proud of this tendency as being "realistic." We proudly resent being a frivolous Pollyanna. We do not know how profitable a stubborn Pollyanna can be. Here is a simple but unnoticed example.

We resent pesky insects and invent pesticides to pollute the environment and 
kill off bees we need. This is negative approach wasting money and hurting Mother Nature and all of us. Instead, we can capture poisonous snakes and killer sharks for tonic delicacies. We can round up scorpions, rats, roaches, flies, mosquitoes, grasshoppers, and any bugs we resent, and then powder them into dog-foods as protein supplement. Making money on this business-profit is substantial—will stop killing elephants and lions (limited profit), and stop making unneeded pesticides, to save money and nature. This is positive approach to pesky living beings, now turned into positive uses. Medical Dr. Brad Mascuch raises his eyebrows twice on this proposal. One, many of them are poisonous. Two, we must not destroy natural food-chain by destroying those living beings. I respond this way. One, our technology should be able to clean up their toxicity. Two, my proposal left open the problem of quantity. We need not wipe out a whole species, much less all species. We could just take away as many as we see fit. After all, we do use antibiotic to kill off excess bacteria to restore our balance with bacteria, to heal sickness.

We have seen two points, that all things have two sides, and that we are obligated to live positively. Now here is our third point. Sadly, however, we do not realize that the contrary to our disdain of being a Pollyanna is actually the valid case, as shown in the above example of benefiting from troublesome insects. Merely struggling to find the positive side of things lifts us up from moping around hopelessly to go defeated. Even if we keep failing to find positive aspects to negative things, our struggles themselves keep us above quicksand of despair. I must confess to having failed so far, however hard I have tried, to find anything "positive" in the Trump regime. I would really appreciate anyone telling me of anything positive in this regime. All I see so far is Shakespeare's adage, "All is well that ends well." I do wish Trump ends quickly for us to be well!

In addition, fourth, this struggle of ours prevents us from falling into a futile sort of Pollyanna, as flexible struggles keep us being aware of actual difficulties that surround us, against which we must struggle. Awareness of difficulties keeps us from being an irresponsible Pollyanna. The joy is solidly and actually great when, by any chance, we do find positive approach to negative difficulties.

In addition, fifth, after all, if anything, being a Pollyanna must be better than being a sourpuss to unreasonably spread depression in the midst of sunshine. And so, relentlessly positive thinking has its positive power that no one can refute at all. We simply must try to live positive thinking, and thereby try unconditionally to live up to its robust upbeat, no ifs no buts. Besides our dealing with insects, more examples abound in daily life.

I asked my sister to pray for me against my tending to be tired and to sleep often. She said I ought to be grateful, for so many people cannot sleep! I have not thought of such positive side to me being sleepy. Another example is pain. No one likes pain. But as pain comes, it begins to initiate joy. So pain begins joy. Many geniuses have been in sickly pain for life. Pain can support genius. Pain is fire burning to bring out the solid diamond of pure genius. Such is a positive side to pain. 
A third example is this. I used to condemn conservative fundamentalism as rigid heresy that plays god in being self-righteous. I now see how fundamentalism dares to press matters to their logical limits. It rightly judges good as good, bad as bad. It dares to claim that God made some people so as to destroy hem. God predestines Jeremiah 1:5 to be his servant prophet before he was born. Likewise, God must predestine some people for hell. Double predestination is here! Wow!

"But how do we do it?" Answering this question makes our sixth point. Well, don't you like the weather? Wait a minute. Wait it out! "When in winter, is spring far?" asks sensitive poet Shelley. Winter is the spring of springtime. When these nasty things begin to happen, we must dare to lift up our head and our heart, never hide, and much less flee. Such stubbornly "unrealistic" optimism does make things positive to actually happen. Stubborn Pollyanna can be stubbornly creative of things positive.

In this creative stubbornness things not only appear as two sided. Things will have positive sides, always smiling at us. Our stubborn optimism makes things positive to come over on us. Pollyanna-optimism no matter what is mother of being creative, as creativity in turn gives birth to persistent optimism. Creativity and optimism inter-birth to inter-empower into novel actuality in persistent sunshine.

All this persisting way of positive living is the panacea to long life, as constantly exhibited by those alive over one hundred years of age. We ourselves are the captains of our days. We are in control of our self and of things, for ever! Now, positive thinking can go in at least three progressively interrelated directions. One, we can see and make at least one positive side to things, as each single day goes on, one after another.

Two, we can see and make both a positive $\mathrm{A}$ and a positive not- $\mathrm{A}$, and going either way is both good and positive. Three, we can see and make several positive outcomes to the daily situations. In all, in these three alternative ways, smile erupts with its both arms stretched out to embrace each of us and each of our neighbors. The more, the merrier. Merry smiles are going from one incident through two to several and more!

When such progressively positive thinking comes over all of us this loving way, negative hatred just goes away. Enmity of whatever sort is now nowhere. Actually, enmity is shoveled aside by positive Pollyanna, as a negative side of things. By chasing enmity out, positive thinking gives us peace contagious, as it continually chants the cosmic music of all spheres. Such music sings joys together on and on. Positive thinking thus pushes me up to show me to me and to my beloved others, to show "I myself as my other" joining hands in joy. And then I myself, all satisfied, vanish nameless in history that is now alive in me. Let us put in a performative way all these six points on positive thinking. To prevent matters from getting too complex out of hand, we stop counting this theme as the seventh point, but clearly this theme is closely related to the previous points, as all others are related to all others. 
"All existents" are made of non-human beings and human beings, and we can learn from how to coexist with non-human beings, so as to extrapolate from this nonhuman "how"-with to a more complex coexistence with human beings. Natural science and technology have been learning a somewhat set pattern of nonhuman existing, from viruses through scorpions and snakes up to wolves and tigers, and devising methods of reverential inter-existing accordingly, each time different in each case.

For example, we humans must survive microbiological attacks, and so we are forced to use antibiotics to reduce the amount of killer-viruses to the level of our manageable symbiosis with them. Our concrete level varies with various concrete situations, and we depend on medical expertise to carefully weigh each case and determine how in each situation to manage "how" to survive with viruses so many.

Now, we need a parallel study of human-scorpions of brutal exclusive Hitler in his unthinking racism. Here there also exist some discernible patterns, though perhaps vastly more complex ones, of appearance, to constitute a phenomenology of human viper-ism. We can learn from scientific harvests of animal patterns to harvest qualitatively much more complex human patterns of life-appearances. The same respect of ferocious animals-a part of reverence for lifeapplies to human bestiality no less lethally toxic if not more. Only respect of poison can adequately devise an effective anti-poison. No respect, no adequacy.

We must learn from bestial human beings to devise an as effective method of anti-brainwashing. They are the brainwashing techniques that those bestial persons consistently use on innocent victims. We must extremely sharpen up our traditional methods of education that tend to be so slow and ineffective. To make effective our traditional educational methods, our education must learn from effective brainwashing, as we stubbornly follow our humane dreams that stretch ahead on and on.

In order to do so, we must stress again. The respect of anti-life threats to humanity runs through, similarly, all our managements of ferocious animals up to their applications to managements of bestial human beings so anti-human. Our future task consists in developing effective anti-anti-life managements. It is fabulously wide-open. To be concretely effective here makes up our quite strenuous uphill battles.

Now, here is another spin-off from time logic that is concrete. The concrete is not a static description of static things but a struggling verb that enlivens days, one day at a time. Fortunately, such daily struggles to concretize are both natural and enjoyable, as all children engage happily in the concrete each day; this struggle is their fun playing. We adults are all children bubbling up constantly with dreams of togetherness that are our persistent myths we all persistently play to actualize.

We all eagerly grab such concocted myths that pull us ahead; these myths are our "plans." We struggle to concretize our plans into actuality, as we struggle to concretize our fond dreams. Our dreams for world concord-heartfelt together- 
ness-die hard, as we all have been struggling for quite many centuries. In fact, we have been struggling since the world began that began with fatal battles to fight against them.

But very soon after our mythical plans are actualized, we are confronted with our own dissatisfactions with how defective our dreams were and how ineffective our successes are. Our dissatisfactions provoke us into creating more new dreams and more new myths, and we are now launched onto struggling for our new plans to take effect. Our dreams of world concord have thus been revised and "bettered" countless times for centuries, and we are still bettering them today.

As we are constantly dissatisfied, we keep creating new myths, to keep struggling ahead. Such is "progress" that steps us ahead constantly. Thus myths go into their concretizations, while concretized actuality provokes creating more myths and more struggles. Human history is composed of such uphill progress without ceasing, and no one knows in what direction such "progress" would go. We humanity simply go ahead. "Going ahead" is the core of history, no matter what and no matter how. History pushes us ahead into managing win-win together in joy together.

\section{Forgiving}

Surprisingly, forgiveness flows from creditor to debtor of all sorts, and back. Forgiveness-flow is an unnoticed necessity for survival of both the forgiven (as expected) and the forgiver that is quite unexpected. As feeling for others is not for others, so forgiveness of others is not for others. I must feel for others enough to forgive them for me myself to live at all. Without feelingly forgiving others, I cannot live on. Forgiveness-flow as the creditor's necessity to live must be explained.

When I pile on my bridge the loads of debts others owe me, the loads prevent me from going through the bridge. Worse, as the loads pile up, the weight of the loads will eventually collapse the bridge. The bridge is myself (and others). The other side I must go to is my future and my others. Unable to go across the bridge now nowhere to the other side, I cannot live any more. I catch the illness to death, such as cancer.

Need we to mention an even worse scenario? We are so easily drawn into an unending series of hateful reprisals. Of course we are never wrong. Of course they are always all-wrong. And so we always suffer injustices done to $u s$. Here is a comfortable breeding ground of "righteous war" to right their wrongs. We must fight for the sake of attaining peace. Tit-for-tat retaliations against their wrongs done us brutally continue to redress "injustices to $u s$." All this while, we are not aware that killing makes no peace, no one can fight into peace, and doing wrong corrects no wrong.

Nothing is pretty in such narcissism-trap of "we are forever right." Exclusive self-love will inevitably drown in its own exclusive self-love. All such continuation of bloody battles spells a literal "dead end" to us all. A grave is waiting for us 
as well as for them. Variously pretty jargon and legends are collected to "white wash" this grave that accommodates our bones and their bones, all so many.

This grave of ugly bones somberly tells us these plain facts. They are that "fighting for peace" is a plain lie, and the "war to end all wars" exists nowhere. This ugly grave is a somber "dead end" to such pretty rhetoric as fight for peace, war to end all wars. Our proud "righteous war" simply butchers us all, "we" as well as "they." All such pretty rhetoric actually kills them and kills us. Our pretty rhetoric lures us all to death without discrimination.

All this brutal zero-sum game has only losers and their bones, as "victors" die with "losers," and our proud "justice" is a killer-vanity. Death stench pervades everywhere, as long as we refuse to forgive their annoying "injustices to us," and let go of our pesky anger, big and tiny. Japan is one most renowned world where loyalty to death to hatred to death is celebrated. Heike Monogrtari and Chushingura are best known, but there are many others, some of which are collected in by Morris. Its reference is Ivan Morris (1975), The Nobility of Failure: Tragic Heroes in the History of Japan.. It is now out of print, perhaps because of its death stench, mostly unjustified. "Not forgiving" kills one another to kill us all. "Forgiving" lives to let live, to begin our win-win co-thriving.

And so, the best for my own survival is to throw out of bridge all the heavy loads of debts others owe me that cause so much anger as to stunt my very living. Those debts must let go of to let flow away in the water of time that constantly flow yonder beyond my hate and anger here now. I must forgive and forget all such unneeded loads from others that weigh me down to death. These loads are not mine, anyway. They are what others loaded onto me, and I as creditor have a right to forgive and forego such foreign stuff loaded onto me.

Now I am free of their pesky ugly debts. I can freely flow in the water of time into new future. I do not need to even swim in the water. I can freely walk on the bridge toward others and hold hands with them, as I walk into my own tomorrows. "Forgiving others" makes me to flow into my free self, as my forgiveness makes me to flow into others in friendship. Forgiving them actualizes my self. I now resume my daily living in free social give-and-take. I need not separate me from those I should not mingle with, the debtors. Forgiveness is time logic that enables me to flow alive with all people without discrimination, world without end.

Interestingly, the same point on flowing forgiveness as life-necessity can be made from a different but similar perspective. Quite often, a person unwilling and unable to forgive others is a Narcissus. Forgiving oneself is another theme. It requires another exciting exploration. He is too much preoccupied with himself to think of others, much less of forgiving them. This Narcissus thinks that he is eternally correct while all others are wrong. And so, he is always a victim of injustice. He is always unjustly treated by all others. Of course, he can never forgive them. He can never in fact forgive anyone who happens to annoy him in anyway! He never owes anything to anyone. It is others who owe him always. He is never willing, and able, to let others' "debts" to him flow away in the river of 
time.

The inevitable result of all this is as the myth-story of Narcissus tells us. Self-love of Narcissus has to drown him in the flowing water, for he is so set in himself as to be unable to flow in water. He has to die to his dear self who is unwilling to flow with water of the world composed of others.

Hoarding his self and holding himself against the flow of all, he holds himself against all others. He forever refuses to share his cherished self with others. As he hoards himself by stopping the flow to flow his self, his self rots away. He kills himself by loving himself exclusively. He can never fulfill his self by excluding others. Unforgiving of others in self-pride kills himself proudly. Exclusive selflove is a death-trap to the self.

One can let go of oneself flowing into others as one lets go of others flowing in their own ways. Such a free-flowing one into another fulfills oneself by fulfilling others freely flowing into themselves. One kills oneself who is unforgiving of others so as to protect oneself against others. In other words, Narcissus loves himself too much to love others. He is not aware that, loving others by letting go of their "atrocities against him" is truly to love himself. Flowing into others flows into me. Stopping me flowing into others rots my own self. Because "loving them loves me," I must continue to "love my neighbors as myself."

\section{Flowing Enlivens}

An important point is made in all these examples above. It is that the flow of things enlivens all things and all situations. The flow enlivens things by sharing benefits. Sharing things to benefit all around makes you win to make me win. Each one is now a winner of benefits continuous. Everyone continuing to win makes everyone alive continually, as benefits feed vitality continually. In this process, I win benefits because you win benefits. Such is win-win management. Such management keeps the society vitally going on and on alive, without ceasing through all time.

History through time now comes alive and becomes meaningful, all due to the win-win management. Stopping this flow of win-win management stops the flowing life of each of us. In fact, such stopping stops the life of any society. Win-win management is absolutely indispensable to the vitality of every single existence in the world, to keep the world alive on and on without ceasing.

Let us look closely into how surprisingly fecund "flow" here is. The win-win flow is an intimate sort of reciprocity of sharing that spreads forward. We see here two factors, reciprocity and spread. To begin with, reciprocity goes like this. You win because I win. I win because you win. What goes around sharing comes around shared. Such reciprocity of sharing benefits as you win and I win, the one winning because of the other winning.

And then, this reciprocity of inter-winning in inter-sharing inevitably spreads on and on ahead, and the spread is the flow forward. And so, the flow is structured in three ways of sharing-reciprocity, need-satisfaction exchange, and spread on and on. First, I may care for ten people. And then, at least one of them 
will come back out to care for me back when I need caring. Caring in feeling-for-you is such reciprocal co-responding. What goes around cared heartfelt comes around caring heartfelt.

And then, secondly, this reciprocal go-around takes a concrete form of $e x-$ change of mutual needs and their reciprocal satisfactions. This is a mutual feeding back and forth of need-satisfactions. In the exchange, you-win for me to win, and we turn out winning together. This is an exchange of hands in goods and in their consumptions, including the "goods" of power, money, talents, agricultural produce, manufactured industrial goods, and the like.

Thirdly and finally, this win-win reciprocity in exchange of needs and satisfactions inevitably spreads-as everyone is actually supported alive by such commercial exchange of needs and satisfactions-far and wide, world without end. All of us turn vigorous and alive thanks to such win-win management. Specificity spreads ubiquitously. Win-win management powers the spreads personal and universal. Each of us wins because of the other. This winning goes to and fro, round and round, far and wide, constantly forwarding spreading.

All this describes the flow forward of sharing the win-rounds. It is in this way that things as water inevitably flow forward. Stopping this flow rots things as water rots when its flow is stopped. Even power, money, talents, and many other precious things corrupt when robbed (from the poor) and hoarded (among the wealthy). The world today sadly shows plenty of rot-riches. Now, let us go to two important features of win-win management, to wit, the care the win-win spread needs, and the basic feature of the win-win, to wit, thinking at the base of life.

\section{Care Needed in Win-Win Management}

First, here is the careful side of the win-win deal. Believe it or not, incredibly difficult is the win-win management. Each situation is a unique "egg" that requires specific weeks to incubate and hatch-to be readied for win-win benefiting. In arranging the win-win thriving together, we must go extremely slowly. Going slow takes time in patient discernment of each situation unique in its peculiar ways.

Since we differ from you, what we think will benefit "you" may inadvertently hurt you. We must patiently observe. We must undergo with you through your incubation days. All this while, this egg is silent never moving. It must take days before it breaks itself from inside it. Our impatience will break this egg from outside, and the situation is destroyed, completely incapable of win-win to inter-thrive at all. All this careful undergoing takes time.

Besides, saying all this is easy. Patiently to go through it is quite another matter. Patience passively undergoes, never taking an impatient active initiative. $\mathrm{Pa}$ tience simply waits and sees, and waits and sees, world without end. Such a performative stance is never easy. We often easily turn impatient, and break into the situation. We break the egg from outside, for we cannot wait for it to naturally break out from inside.

“How can we do patient waiting and watching?” Love suffers long, they say. 
"Love" is intense concern in silence. Love can suffer, suffering disappointment, suffering "letting things transpire" as they naturally incubate. Such twofold suffering takes patient time for a long time. I cannot repeat this important point often enough. Such suffering love takes a long slow time.

Being lovingly concerned can be patient for long, far longer than we can "reasonably" bear. This unbearable patience can go "forever" as it seems, when all of a sudden, the egg-situation will pop to break itself from its inside. Remember Augustine's mother Monica. Monica prayed for him for several long decades, until her son finally turned from an impossible rascal and playboy into a saint for all time.

Thus, we must absolutely keep in mind two points, in trying to benefit you. Each you-situation is an egg so recalcitrant, and each egg-situation differs from all others. These two points-recalcitrance and difference-compose an "impossible" hurdle to our goodwill to benefit you. Trying to benefit you takes an infinite variety of skills for an infinitely long time.

We must patiently continue to scheme variously in infinite patience, so as to discern various egg-situations and try to fit our offers snugly to each unique egg-situation that is unique "you." Win-win management is never easy. But as difficulties are many that requires infinite care, so the win-win management is of enormous value. Here ends the first point on the win-win, that it needs care.

\section{Thinking as Win-Win}

Now, here is the second notice about the win-win management. It is that the win-win is basic and inherent in our thinking that we innately do. Amazingly, our thinking itself is a win-win deal, where matters are shared and continue to flow from one person to another, on and on. An explanation is in order. Let us begin with music that is our bodily rhythm to sing on living onward. Music thoughtfully singing is forever happy.

We live for music. We live on music. We live music. This is because music delights health. Our health simply sings music. This is again because music tunes us into the rhythm of life that is itself music in heartbeats and in lungs breathing. All healings perform music. Musical therapy effectively helps medicine because music is the whole medicine itself. And so, such healing music is ever happy.

Happy music is ever one with thinking and thanking in life, in this way. Thinking is the basic twitch of my bodily mind. This basic life-act of thinking is famously linked to thanking in etymology. Heidegger idly made a huge splash over this denken-danken connection. Their connection is puzzling but full of very significant connotations. $\mathrm{O}$, how I wish my every thinking is thankful all heartfelt and singing all the time! I would be an eternal Pollyanna without silly giggling but each day filled with happy musical time logic, solidly thoughtful and forever thankful.

It is obvious that, when you win because I win, as I win because you win, we are naturally grateful for one another. The win-win management would easily enable thankful thinking to sing forth our spontaneous music, even "without 
thinking." This win-win performance into thankful thinking would instantly produce the heavenly paradise right here and now on this daily imperfect world of ours.

St. Paul's casual but seemingly impossible injunction (1 Thessalonians 5:18), "In everything, give thanks," would now happily come to pass, without even trying. Here, how could we help smiling in gratitude? Here, how could gratitude not be thankful thinking so inevitable? Holding hands one to another, our thankful thinking continues to sing our happy music in and beyond joys and sorrows. We now think on thinking.

Thinking is a dialogue, says Socrates in Theaetetus 189E-190. Obviously, dialogue naturally began with hearing and talking. Such initial dialogue was of course orally executed. Dialogue began with my self talking with my self in silence, or talking to myself aloud.

And then, sooner than later, I turn to talk with you as I think toward you and respond to your thinking and talking. During this thinking dialogue, we orally influence one another to be changed by one another. In oral dialogue, we tend to repeat what is said to reinforce our memories and influences. All sages did so, and then their disciples began to write down those memorable dialogues. Oral dialogues turn alive on paper through time.

Oral tradition was now written down into books on paper. From now on, reading dialogue took place to replace oral dialogue that had come and now went away. Formerly, ear-dialogues provoked oral responses and then flashed away. Now sound dialogues turned into eye-dialogues that stay put and last long. Oral repetition of the theme turns into repetition of reading the same page. In the reading dialogue, one side is settled unchanged, while another side reads again and again to change the reader's mind. Hitting on the stable side on paper, the reader-side is provoked to respond with "yes, but," and a new "system" begins to appear on the horizon, in this way. First, the reader is provoked to agree on some points, disagree on some other points, react with "this point is missed here," and "this point is not clear, for I do not get it." And then, these reactions come to assemble together into a new system of reader's own. Such is thinking.

Thinking is dialogues are made by mixing monologues and dialogues. Monologue is a dialogue conducted within the personal self. Dialogue is monologue visibly and objectively come alive. Such dialogue as monologue, monologue as dialogue, provoke forth "yes, but" that is a creation of myself. Thinking is creation of one's self spanking new, out of initial nothing.

Creation is always new creation, and new creation is all divine. Thinking is thus an act of divinity quite exciting. This divinity is monologue in dialogue, alive and creative, all spanking novel. Thinking as divine is trinitarian, dialoguing with itself, with another self, and with many other selves. Thinking is trinitarian creation spreading onward, world without end.

Thinking is thus alone with the others, each of whom is alone. Thinking is a monotheism spreading in polytheism, all-creative out of nothing. Creative thinking is a self-change living on other-changes, first in oral others and then in 
visual others. Thinking is alive, constantly self-deepening to depend on others, as all are reciprocally deepening. These others are the partners of dialogue who can be oneself diversifying into many "one-selves." Thinking is alive, constantly self-diversifying with others diversifying. Thinking is such divine wonder of all wonders.

These thinking monolog-dialogues tell us that we are inherently social quite alive. We cannot live without socially dialoguing, orally with ears and visually with eyes. Still, all this while in constant dialoguing, each of us remains quite alone. In thinking, we ponder deep to diversify, all in a complete solitude. We are always together while we are each alone. We are by nature social in solitude.

And we should never forget that all such social solitude is quite pleasant. Our monolog-dialoguing is sheer beauty heartily to sing and appreciate. We enjoy oral give-and-take with historic Socrates, as we enjoy conversations with contemporary Mark Twain. Such monologue-dialogues are themselves to be sung heartfelt in mindful pondering, continuous. Thinking is sheer joys of social solitude.

In addition, we are in complete joy in dialogue, as we gloat here now over the historic Chinese calligraphy since at least $300 \mathrm{AD}$. Calligraphy in front of us here is the unity of ideograms and poetry for millennia. Here beauty of ideograms 文 字 is beauty of written expressions 文. Ideograms in calligraphy jump out of history to dance with their viewers-quite alive on paper heartfelt "here now" throughout history.

Here in our appreciation, subjectivity is melted into objectivity inter-creating, as they inter-chant their intense joys together. Truth and goodness are rounded up by beauty to sing the Music of the Spheres quite inter-personal. It is thus that thinking is alone and together, personal and cosmic, both inter-composing to inter-chant each other. In this way, all create all in thinking monologue-dialogues, on and on.

Such thinking is so delightful and so overwhelming that we are glued on to it at each moment. Thinking is personally cosmic, in silence so loud in conversation, and in vision so deep and vast in reading. All are welcomed, as each is coming alone whistling. Such thinking alive routinely performs win-win deal where everyone is happy from one end to the other. Thinking is by nature win-win joys contrived unawares. Now, thinking as win-win joy is one basic example that typifies the art of living. The art of living is the basic beauty that is itself a win-win joy.

\section{Art of Living Culminates in Win-Win Deal}

Now, we must notice that the win-win deal is the summit of the art of living. The crucial importance of "the art of living" must be explained to reach the happy win-win living. We have seven points. First, our mere living itself composes an art of living. As I live on, I keep completing its art, and at the same time, each day I have just begun crafting its art. I am the master and the apprentice of the art of living that is of course jumping alive. Secondly, this art is supreme. It is the 
master-art of all arts. All arts begin here to develop in their various ways, only in order to return here as their home and their supreme culmination.

Thirdly, living is the art of all arts, and we are all living. Because of both facts being at one in this art, we are special artists of living, though some are more artistic than others. And each day we live on more excellently than we are now. We do aspire each day to live richer and better than the days before. Fourth, even what "better" and "richer" are, we learn by actually living on differently every single day. We learn what better richer life is by living life itself.

Fifth, we live and learn one day at a time, never two days or half a day at a time, or else three days or more at a time. Time is thus quite time-logical. Never random or arbitrary, time performs its task in the way of "time logic," one moment at a time, and one day at a time.

Sixth, in this time-logic way, our art of living is a process now and a promise of the future. Both are arduously uphill climbing and are excitingly enjoyable. Let us look closely at, first, the art of living as an arduous uphill struggle, and then consider this art of living as an enjoyable excitement. So, our sixth point has two features, arduous and enjoyable. All this shows how rich and good the art of living is.

To begin with, our art of living is arduous because each of us is often daunted differently by various hardships in daily living. I am forced to tackle the difficult problems that keep coming over me, each in its different way from others. Their variety adds colors and challenges each single day. The art of living is various, daunting, and exciting. Besides, my art of living comes out excitingly different from yours that is in turn uniquely distinct from hers. Each of us is the master of this art, because each personally lives this art of living. And this master is the apprentice who keeps learning each day, each time differently from other days. Being master and learner in the same person indicates how intimate an art is this art of living.

And then, this living-art is enjoyable in that this art is the master-art of all arts. This master-art then splits into many subordinate arts that are usually just called "arts." In contrast to the art of living where the master is the same as the learner, in these various arts, masters are split into various art-masters and separated from their learners. Now, separation of master from learner makes learning an objective affair. What is learned is out there separate from the learner's learning, quite laboriously.

As a result, personal participation comes to be stressed as important. Learners must be personally involved in the art they learn. Learners must personally experience the beauty of the specific art they objectively learn. They must be personally excited at the beauty of the art they learn. Being personally inside the art is the sine qua non to mastering the art. And so, "the learners must live the art they learn," stress all masters of all these arts.

But then, living the art is none other than the art of living. This means that any usual art must become the art of living in order to become the art truly and really so called. What goes around comes around. The arts that develop from the 
art of living, now come back home to this very living-art. Such homecoming of all arts to the art of living amounts to showing how all arts come out of the art of living and then return home to their originative art of living. After all, we are all living, and the art of living is our basic home-art.

Thus it is that the art of living is the master of all arts. This living-art supremely embraces all arts, all masters, and all learners. Isn't such existential fact of the art of living excitingly enjoyable? This excitement is deepened when we see the apex of the art of living, and so the apex of all arts under this living-art as well. This apex is the win-win inter-joys of inter-involved thriving-together. I am we and we are I in reciprocal joys of the beauty that is the art of living as art.

Seventh, this final point culminates our art of living in the win-win joy. You will inevitably ask, "How could we perform our art of living?" Let me put it this way. Living is part and parcel of the river of time. No one can step into the same river twice. To breathe living is to differ every moment I breathe. I do sometimes notice the difference in my "same" breathing to realize that I am living. I then adjust my day accordingly to fit the constant differences that come. "To differ and to adjust to fit" amounts to being an artist of living.

Being different is the usual fact of living. To adjust to fit in is its art its beauty. To adjust to fit needs first to watch the daily changes. I must watch how this moment differs from that moment. This watchful discernment enables me to decide on my proper fit into the next moment that immediately follows this moment when I watch. Constant change demands constantly alert watch. Each moment is spanking new, and I have no way of getting used to the momentary effort at any moment.

Watch and renewing are two keys to knowing the situation here now. And then, I must at once design a tactic and decide on it to adjust me to fit the moment here now. I have no time to lose in hesitation. I must repeatedly watch and act on my designed tactic, and such skillful repetition composes being artfully alive. Such artful living has no dull moment. Each moment is spanking new and straightly exciting. All this means that living is a gambling of this sort, and a gamble is exciting.

Now, the goal of this life-adventure is win-win happiness together, brand new at each moment. Of course as I change you change, too. The process of change to adjust is now compounded. Matters now get complex and difficult. But both you and I can engage in the win-win deal. Watching each other, each of us can adjust each to the other. Our purpose is to reach the situation where you win because I win. We continue to reciprocally assist each other to let you benefit because I benefit. All this win-reciprocity makes joy compounded, indeed. In such reciprocal cooperation toward our win-win joys, we will eventually rejoice together as we hold hands, ever.

Now, to make this long seven-point story short, we say that we have found this fantastic fact. We all live for joy. The greatest joy is win-win happiness together. The art of living has then to be an art toward the win-win joys. Thus the art of living inevitably culminates in the win-win management. Our supreme art 
of living that embraces all various arts is sheer beauty. Our beautiful art of living is the sheer beauty of win-win management. No more can be said. The win-win management must be done for the sake of supreme beauty of reciprocal joys won together.

\section{Conclusion}

Let us now thread all details above into a coherent win-win interactive management. The win-win simply must happen. This point cannot be repeated too much. The win-win is unconditionally essential to human nature. The win-win management is indispensable to human survival. We either thrive together in win-win happiness, or else die isolated alone, by robbing from others to hoard what "I" want. Either thriving together or else dying isolated-life in all senses has no third alternative.

Let us put it another way. We have no third alternative because we are innately social. Being social means how always double we are. The win-win deal makes double-positives, joy-joy in thriving-thriving. The zero-sum performance is positive-negative doubled. Here we win-lose into living-dying. These are the only two choices we have. We have no third alternative of choices, for our being social means that we are always doubled as above alone, never tripled or more. Dying isolated is no fun, so let us detail the alternative of delightful joy-joy co-thriving.

Here in the win-win situation, I win because you win. Because you win a loaf of bread you need, therefore I win money for the cost of bread I have made. This is "commerce," which is the pivot of economics on which our society turns. Commerce performs economics. "Economics" is "oikos-nomos," which is household-law of management. In the family, care is poured on the young, the sickly, and the sick. The weak family members win meticulous caring, so as to win accolade for the strong.

The weak win loving care for the strong to win adoring respect. Here, one party wins because another party wins. Commerce performs such win-win family management in the society where one party wins (money) because another party wins (bread). Each party wins because the other party wins. Does all this sound abstract? Look. Let me give just two concrete examples, power and money.

In the win-win power management, your power grants me power to contribute my new prideful strategies to better each other. Your money grants me some financial resources to invest in public welfare to better our living conditions. Money thus flows from you to me to all of us. And of course you in turn are happy seeing the delightful harvests out of your seed-power and seed-money you invested.

This is commerce that spreads from you to me to all community, on and on. This commercial inter-benefiting is the bottom-base that supports and enlivens scholars who theorize, agriculturalists who produce farm-products, and industrialists who manufacture goods for consumers. All such exchanges of produc- 
tions and consumptions have no loser. Everyone benefits by someone else's benefits.

Sadly, however, we seldom practice this delightful and essential win-win management. Why this poverty situation holds for so unendingly long in world history is sadly unknown. Instead, the zero-sum competition always holds sway here. The cutthroat zero-sum competition inevitably produces losers. Now, a small notice is in order here. Zero-sum competition is a competition in which the sum of competition must add up to a zero. And so, the winner as a positive must be added to the loser as a negative to make up a zero.

This necessity amounts to saying that zero-sum competition must always produce losers (as it produces winners). This "must" composes world tragedy for all time, continuing as long as the zero-sum contentions continue. For reasons we do not know, we are never tired of being stuck in this unnecessary tragedy. And such tragedy spawns all sorts of unexpected offshoots. One unsavory example is enough.

Here is an odd statement declared by, of all persons, a Christian fundamentalist. The saying is strangely reminiscent of zero-sum brutality. The statement says, "God creates some people in order to destroy them." Wow, how cruel! This statement must have come from two sources. They are God almighty and human history. Let us go into them one by one.

One, God graciously told Jeremiah (1:5), "Before you were born, I ordained you a prophet." Wow! What honor! In elation, the proud fundamentalist, by parity of logic, inferred the negative to this favorite passage of theirs, because they arrogate themselves to be another Jeremiah-without proof! They in coldblood infer that as God has ordained honor to some Jeremiahs, so God must have ordained destruction to some other shady people. Two, actual history indisputably reports some heinous tyrants who remain amply deserving of destruction. And they quite often ended in their own destruction, either by themselves or by others. There is no doubt about this fact.

Now here is our counter argument, one by one, against the above-divine love and human freedom. One, their parity of logic is valid only on the assumption that God is almighty alone. But the Christian God is almighty in love that unconditionally accepts us all. That is why this special love is divinely "almighty." Divine love spins out incredible dramas that exclude predestination of destruction to any people. God's ordaining before our birth is tilted in love to our honor, and there can never be a "parity" of inference due to almighty divinity as almighty love.

Two, the history about tyrants is derived not from double predestinations. This history just reports human decisions and their responsibilities in their aftermaths. Tyranny derives from human freedom. Tyranny is never compelled by fate of divine predestination. History is never a record of divine fatal determination of condemnations and destructions. History is a record of human performances of human freedom and their resultant bloody disasters. And so, tyrants are not fated by determination of God. Tyranny is freely chosen by us human 
persons.

In short, God's Love and human freedom have no room for fatalism of negative predestination. In other words, the above statement, "God creates some people so as to destroy them," excludes God of love and freedom of persons. Exclusion of love and freedom indicates that this statement, even though it came out of a Christian fundamentalist, is not Christian but coldly pagan. The brutal zero-sum competition is projected onto the Beyond and turns into a monster of eternal damnation.

In addition, we must take note of this important fact. Not all competitions are of a zero-sum sort as described here. Awards for excellence are a case in point. Nobel laureates win applause, but "Nobel prize losers" sound strange if not unintelligible, for those supposed "losers" actually lose nothing. They remain as they are, and they are often as distinguished as before. The summa cum laude graduate has no loser, either. The zero-sum competition is a specific sort of competition where "losers" are sadly necessary, meaningful, and appropriate.

Unfortunately, our world today is filled with zero-sum competition to continue producing losers at the drop of a hat. Dissatisfactions of the losers in worldwide zero-sum competition are all over, and they continually destabilize the community. Instability cannot be tolerated, in that social unrest devastates the society. And so, negotiation simply must take place and trans-action must continue until most if not all contending parties, especially the loser-party, are satisfied, to result in ceasing as many dissatisfied complaints as possible.

Now, "many parties satisfied" is the best that the inevitable negotiation can achieve, out of the necessity of the zero-sum competition. But "many parties satisfied" is quite a weak version where there exists no "win," or "because," in the vibrant win-win management in which "I win because you win." Still, this is the most and the best the zero-sum competition can achieve that this win-or-lose competition has to achieve, on pain of social devastation.

Still, the zero-sum competition is what the society at present constantly performs that makes everyone a winner. This is the case, as cited many times above, in today's worldwide commercial engagements. But all of us are at a loss as to why we have to acquiesce in a cutthroat zero-sum competition in the midst of win-win commerce all over the world, and at best attain a diluted form of the win-win management_ of negotiated lack of complaint. In any case, this pointwin-win is much more satisfying than zero-sum-proves how much delightfully superior is the win-win management to the zero-sum competition.

All the above points-zero-sum produces losers, losers destabilizes the community, social unrest disables survival of us all, the zero-sum is forced to adopt a diluted version of the win-win, the win-win deal is actually practiced already in world economy, etc.-come together to urge us to advocate win-win management. This argument for our irresistible joys_-together! — is simply irresistible.

And so, we simply must continue tirelessly to promote the win-win management to benefit all of us in any community, to co-thrive together worldwide, on pain of all of us dying alone in the zero-sum competition. This essay is part of 
this advocacy to enrich all of us. Lest we all die alone, we simply must passionately promote win-win management to thrive together all over the world.

Now, in addition to the above negative urge, here is the positive side to the win-win deal. Time logic is ubiquitous. Time logic throbs in time to gush out logic all over. This logic is quite concrete, as it is typified by four modes of thinking, body thinking, concrete thinking, story thinking. They all join to chant music thinking quite joyous. All this while, we see how these four modes of thinking manifest the win-win logic of appearance in time of time logic. In other words, these four thinking modes typify four modes of phenomenology of time logic in win-win management.

Finally, these four modes of phenomenology of thinking in time logic relate each to all other three and involve these three. To live one mode is to perform all other three modes. When we body-think, we concretely think in story-thinking way to chant music in thinking way. To concretely think amounts to bodythinking in story-thinking way as we sing sonorously in music thinking. To think story-way is to bodily think concretely, to rejoice in soaring music thinking. To music think in singing joy, we must bodily think concretely in story-way, uniquely different from usual logical way.

Such protean complexity boggles our minds as it excites our hearts. We simply love such thinking life. Life is drenched in thinking. Thinking is time logic in love rejoicing together. We are often starved for vitality. As our mind is sick, our body is sickened. As our body gets sick, our mind is wilted ill. We are psychosomatically sick unto death, as we are psychosomatically happy in the whole person and the whole community. On such occasions, time logic as above described is our indispensable tonic toward vitality of psychosomatic, personal, and inter-personal sort. In other words, time logic described here is inherently a win-win management. Let me explain.

Time logic that culminates in music-thinking, chanting madly in joy, would restore us back to our usual healthy days of casual joys. Time logic turns us jumping alive as kids. We are now kids who begin to yet begin, ever! Time logic performs the win-win joy. Anyone would be abysmally foolish who would not jump right into such win-win-management in sheer happiness.

As a result, the win-win situation is now a universal chorus of joys together. Here we are all so wildly happy, clapping hands to sing the world. And this intense elation, even to the extent of stamping feet to forget ourselves, is actually never irrational but quite timely logical. Every lifting of arm and every pointing of finger are full of their own thinking in their own time logic. The whole world sings its time logic as time logic loudly in silence sings the world at each moment of wildly enchanting joys together.

As we watch all this intently, we hear the "still small" whisper of time logic resonating throughout each moment and each locale. Such resonance all around is the music of harmony of all spheres, serenaded by countless small crickets that keep zoo-zoo-ing quite aloud and quite invisible. Small insects are holy angels chanting in chorus the heavenly rhythms up in the sky to resound with joys all 
over here on the ground. We can never miss such universal time logic shouting in silence so loud, chanting in joys after joys all victorious all over.

Hearing all this chorus of nature in musical joys, we human beings cannot help but wave our hands to tap our feet, dancing into joys after joys after universal joys, quite unconditionally, universally, and ultimately. We dance unconditionally, in happiness and in sorrows, night in and day out, at dawn and in the dusk. Such universal music can never stop. We all join in to sing the whole world in wild enchantment, in joy and in sorrows, world without end. This is our inevitable win-win management.

In the meantime, so many birds fly all over as the shy sun peeps out. These countless birds so tiny and all-nameless also encircle all around as the tree-shadows grow long and thick. All children sensitive to birds dance to go outdoors, and then dance to go back home, as these kids sing with these birds chirping world without end. The birds and the kids sing back and forth such cosmic music in timed logic in win-win deal. A kid-song at dusk comes to mind. "Day at dusk, burning on./Temple on hill, gong sounding./ We join hands, go home, all./ Dear crows, go with you, OK?" This stanza translates the first verse in the irresistible kid-song singing Yuyake koyake 夕燒, 小燒.” This kid-song is so well-known as to require no reference. I tried hard to convey its resonance so cute. What happiness chanting all cosmic joys! What happiness this is in the win-win deal all over!

\section{References}

Morris, I. (1975). The Nobility of Failure: Tragic Heroes in the History of Japan. New York: The New American Library.

She, B. Y. et al. (1971). Ancient Literature par Excellence. Taipei: Sam-Ming Bookstore. Wu, Z. J. (2006). Sun-Zi. Taipei: Sam-Ming Bookstore.

Submit or recommend next manuscript to SCIRP and we will provide best service for you:

Accepting pre-submission inquiries through Email, Facebook, LinkedIn, Twitter, etc. A wide selection of journals (inclusive of 9 subjects, more than 200 journals) Providing 24-hour high-quality service User-friendly online submission system Fair and swift peer-review system Efficient typesetting and proofreading procedure Display of the result of downloads and visits, as well as the number of cited articles Maximum dissemination of your research work

Submit your manuscript at: http://papersubmission.scirp.org/

Or contact sm@scirp.org 